\title{
Removal of Fluorides in Drinking Water by Aloe Vera and Calcium Chloride
}

\author{
RADHEY SHYAM and G. S. KALWANIA* \\ Department of Chemistry, S. K. Government P. G. College Sikar-332001, Rajasthan, India \\ gskalwania@gmail.com
}

Received 25 March 2013 / Accepted 30 April 2013

\begin{abstract}
The occurrence of high fluoride in groundwater has drawn considerable attention in the world. The contamination of fluoride in groundwater has influenced by fluoride rich rocks, $\mathrm{pH}$, cation and anion exchange capacity of aquifer materials, bicarbonates, evaporation and temperature etc. The aloe (Aloe barbadensis Miller) and calcium chloride has been used to precipitate out fluoride ions from drinking water. The effect of different parameters on precipitation and adsorption studies like $\mathrm{pH}$, agitation time, adsorbent dose and fluoride concentration have been analysed. The equilibrium adsorption data was studied for Langmuir and Freundlich isotherms.
\end{abstract}

Keywords: Fluoride, Precipitation, Adsorption, Aloe vera, Calcium chloride

\section{Introduction}

Chemically, the fluorine is the most electronegative element and it is always present in a combined state as fluoride because of its high chemical reactivity. The fluoride is a great calcium-seeking element and it can disturb the calcified structure of bones and teeth in the human body at higher concentration resulting dental or skeletal fluorosis ${ }^{1-5}$. World Health Organization ${ }^{6}$ has recommended the optimum range of fluoride to be as $0.5-1.5 \mathrm{mgL}^{-1}$. India has $14.1 \%$ of total fluoride deposits on the earth's crust and the fluorosis is endemic in 17 states $^{7}$. In Rajasthan, 18 out of 32 districts are affected by fluorosis and 11 million of the populations are at risk $^{8-10}$. Various studies have indicated prevalence and severity of fluorosis in many districts including Bhilwara ${ }^{8}$, Sikar $^{9}$ Hanumangarh $^{11}$, Dungarpur ${ }^{12}$, Sriganganagar ${ }^{13}$, etc.

\section{Experimental}

All the required reagents used were of A.R. grade. Fluoride stock solution was prepared by dissolving $221 \mathrm{mg}$ anhydrous $\mathrm{NaF}$ in $1000 \mathrm{~mL}$ de-ionized water ${ }^{1}$. Fluoride standard solution $\left(10 \mathrm{mg} \mathrm{L}^{-1}\right)$ was prepared by diluting $100 \mathrm{~mL}$ stock solution to $1000 \mathrm{~mL}$ using de-ionized water. Further, 1.4, 1.2, 1.0, 0.8, 0.6, $0.4,0.2$ and $0.0 \mathrm{mg} \mathrm{L}^{-1}$ fluoride solution were prepared for calibration curve. The test fluoride solutions of different initial fluoride concentrations were prepared by adding equivalent volume of standard fluoride solution to the tap water. For all experiments, $100 \mathrm{~mL}$ sample volume was used. All the experiments were conducted at room temperature of $23 \pm 2{ }^{\circ} \mathrm{C}$. The $\mathrm{pH}$ of the sample was adjusted by adding $0.1 \mathrm{~N} \mathrm{HCl}$ and $0.1 \mathrm{~N} \mathrm{NaOH}$. 
Aloe vera (Aloe barbadensis Miller) leaves were collected from botanical garden, S. K. government college, Sikar. The leaves were washed under tap water to remove adhering materials. Thick epidermis or skin was carefully separated from parenchyma or gel part. The gel part was smashed to form a transparent liquid and preserved in glass bottles. The known quantity of aloe vera juice and $\mathrm{CaCl}_{2}$ powder was well mixed into sample water. The sample was stirred in the beaker at $800-1200 \mathrm{rpm}$ by magnetic stirrer. The sample was allowed to settle and then filtered through local available Sikar clay.

The samples were analysed for residual fluoride concentration by SPADNS dye method $^{39}$ using double beam UV-Vis spectrophotometer (Systronic No. 2201) at wavelength of $570 \mathrm{~nm}$. Hydrogen ion concentration $(\mathrm{pH})$ was measured by water analyser (Systronic No.371). Adsorption isotherm studies ${ }^{23,28}$ were carried out taking different initial concentrations of fluoride at constant adsorbent dosage. Langmuir and Freundlich models were applied to the adsorption isotherm.

\section{Source of fluoride}

The hydro-geochemistry of fluoride is influenced by some minerals such as include apatite $\left(\mathrm{CaF}_{2}-3 \mathrm{Ca}_{3}\left(\mathrm{PO}_{4}\right)_{2}\right)$, cryolite $\left(\mathrm{AlF}_{3}-3 \mathrm{NaF}\right)$, fluorspar $\left(\mathrm{CaF}_{2}\right)$ and silicates such as the phyllo silicates of micas, the doubled chain silicates of amphiboles and the phyllosilicates of clays where $\mathrm{F}^{-}$substitutes for $\mathrm{OH}^{-}$within their octahedral holes ${ }^{14-15}$. The dissolution of dolomite mineral produces $\mathrm{HCO}_{3}{ }^{-}, \mathrm{Mg}^{2+}$ and $\mathrm{Ca}^{2+}$ ions in the groundwater ${ }^{16}$. The amount of bicarbonate accelerates the dissolution of fluoride through a cation exchange process. The sodium ion in groundwater replaces calcium ion from mineral like fluorspar leading to the dissolution of fluoride from mineral phases into groundwater ${ }^{14-16}$. This type of process is likely favored by the adsorption of calcium and magnesium on clay, micas, schist, gneiss, quartzite etc.

Some favourable hydro-chemical conditions for dissolution of fluoride from silicates to groundwater has been suggested like alkaline $\mathrm{pH}$, excess of bicarbonates, anion exchange $\left(\mathrm{OH}^{-}\right.$and $\left.\mathrm{F}^{-}\right)$and cation exchange $\left(\mathrm{Ca}^{2+}\right.$ and $\left.\mathrm{Mg}^{2+}\right)$ capacity of aquifer materials, long residing water in a rock or interaction system and climate ${ }^{16-19}$.

\section{Defluoridation}

Defluoridation is the process of removal of fluoride ion in drinking water. The process may be classified broadly into adsorption, ion exchange, precipitation (coagulation) and reverse osmosis. Adsorption is an excellent process in which fluoride is concentrated onto adsorbent mass. Many bio-sorption techniques have been employed for the treatment of drinking water. The biomass like Azadirachta indica, Ficus religiosa, Acacia catechu ${ }^{20}$, Tinospora cordifolia $^{21}$, tamarind ${ }^{22}$, tea leaves ${ }^{23}$, micro algal ${ }^{24}$, Hydrilla ${ }^{25}$ etc. has studied for fluoride treatment. The inorganic materials like alum ${ }^{26}$, activated alumina ${ }^{27}, \operatorname{clays}^{28-30}{ }^{\text {, ceramics }}{ }^{31}$ etc. have been analyzed for fluoride removal. Most of the defluoridation techniques have succeeded at $\mathrm{pH}$ less than 7.0.

The potential determining ion in this process has supposed to be hydrogen ion $(\mathrm{pH})$. In acidic medium, hydrogen ion accelerates more positive charge on calcium which favors the precipitation and adsorption of fluoride becomes more pronounced. Another probable factor is the selectivity. This selectivity factor differentiates between the fluoride and other anions i.e. bicarbonate, chloride, nitrate, sulphate etc. The presence of very high concentration of chloride, nitrate and sulfate decreases the adsorption ${ }^{32}$, but bicarbonates affect this process significantly.

The objective of this study is to remove fluoride ion from drinking water by using easily available material. Many plants and herbs have been studied and analysed for their fluoride 
removal capacity. The aloe vera plant has found having some fluoride removal capacity. Aloe vera (Aloe barbadensis Miller) is a shrubby, perennial, xerophytic, succulent plant. It has thick and pulpy leaves. It belongs to Liliaceae family. The medicinal importance of aloe plants has been well known for centuries. It has been used as an ingredient in many cosmetic products. Aloe vera gel has anti-inflammatory, wound healing, anti-diabetic properties $^{33-34}$ etc. It contains a number of nutrients such as sugars, minerals (iron, zinc, sodium, potassium, calcium, magnesium etc.), amino acids, enzymes, fatty acid, vitamins $^{33-36}$ etc. It has been reported that aloe vera has water purification properties ${ }^{37}$. Aloe vera is cultivated in the dry and hot weather conditions ${ }^{38}$ and is growing worldwide including India, Africa.

\section{Results and Discussion}

Parameters investigated in the precipitation and adsorption studies has included as $\mathrm{pH}$, adsorbent dose, agitation time and fluoride concentration. The equilibrium adsorption data was studied for Langmuir and Freundlich isotherms.

\section{Effect of $p H$}

The $\mathrm{pH}$ plays an important role for de-fluoridation process. The $\mathrm{pH}$ of sampling water was adjusted by adding $0.1 \mathrm{~N} \mathrm{HCl}$ and $0.1 \mathrm{~N} \mathrm{NaOH}$. Different water samples have been prepared varying $\mathrm{pH}$ values. The aloe vera $(5.0 \mathrm{~g})$ and $\mathrm{CaCl}_{2}(0.5 \mathrm{~g})$ mixed into $100 \mathrm{~mL}$ sample water having $4.20 \mathrm{mg} \mathrm{L}^{-1}$ fluoride. The mixture was agitated for 20 minute and kept constant for 10 minute (total contact time-30 minutes). The filtrate was examined for hydrogen ion and fluoride concentration.

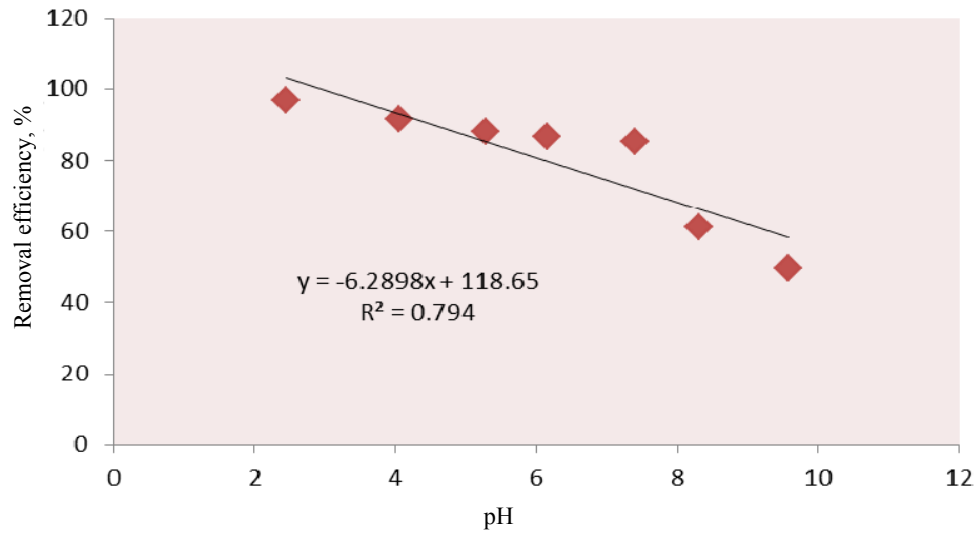

Figure 1. Effect of $\mathrm{pH}$ on precipitation and adsorption of fluoride

The maximum fluoride removal was observed as $97 \%$ at $\mathrm{pH} 2.45$. It was observed an increasing order in fluoride removal efficiency from $\mathrm{pH} 9.58$ to 2.45 as shown in Figure 1. The suitable $\mathrm{pH} 7.40$ showing $85 \%$ fluoride removal capacity was selected for further study.

\section{Effect of aloe vera and $\mathrm{CaCl}_{2}$ doses on fluoride removal}

The extent of fluoride removal was linearly related to the amount of aloe vera and $\mathrm{CaCl}_{2}$. The effect of $\mathrm{CaCl}_{2}$ doses keeping constant amount of aloe vera $\left(50 \mathrm{~g} \mathrm{~L}^{-1}\right)$ was studied as shown in Figure 2. The fluoride removal capacity was found appropriate at $3.0 \mathrm{~g} \mathrm{CaCl}_{2}$ dose having $83 \%$ removal efficiency. Further addition of extra dosage has observed no significant increase in fluoride removal. 


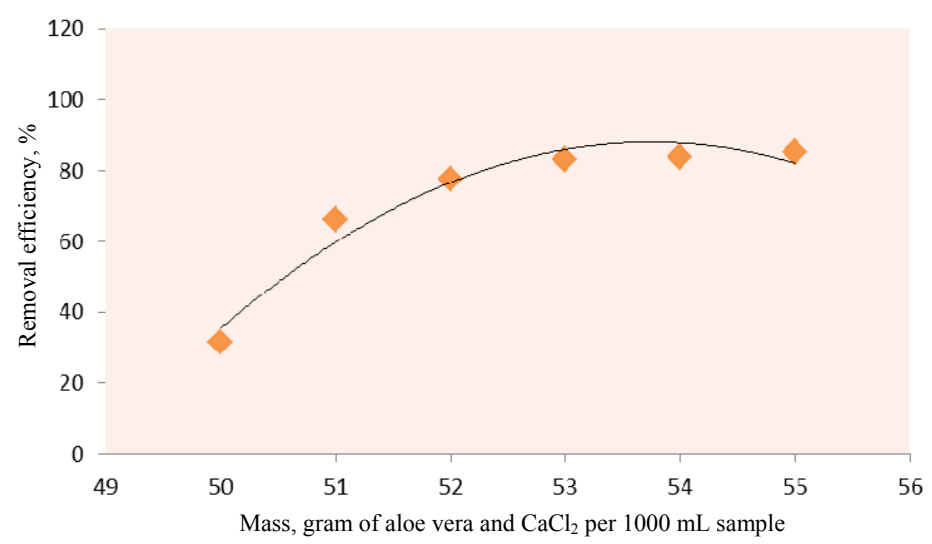

Figure 2. Effect of $\mathrm{CaCl}_{2}$ dose (keeping constant aloe vera) on precipitation and adsorption of fluoride at $\mathrm{pH} 7.4 \pm 0.1$

Therefore, the $3.0 \mathrm{~g} \mathrm{CaCl}_{2}$ dose was selected for further study. The next, the effect of aloe doses keeping constant $3.0 \mathrm{~g} \mathrm{CaCl}_{2}$ in $1000 \mathrm{~mL}$ sample was studied as shown in Figure 3. The aloe vera value $40.0 \mathrm{~g}$ was found suitable having $85 \%$ removal efficiency.

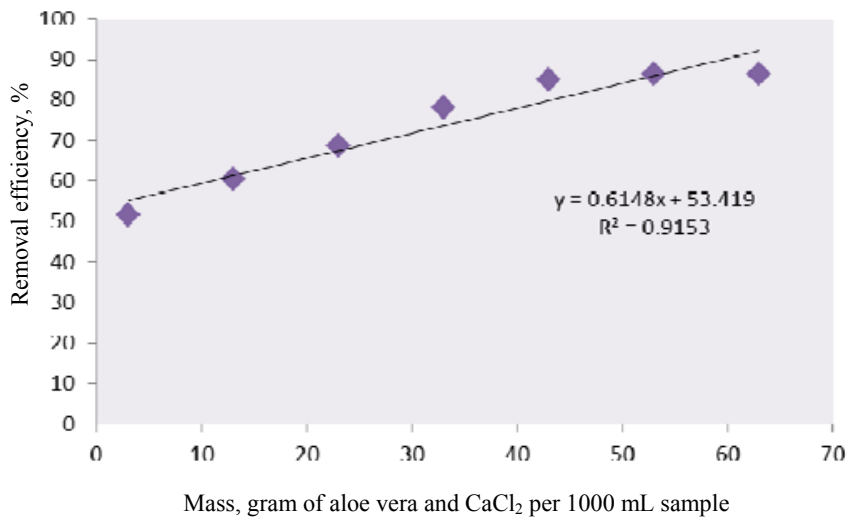

Figure 3. Effect of aloe vera dose (keeping constant $\mathrm{CaCl}_{2}$ ) on precipitation and adsorption of fluoride at $\mathrm{pH} 7.4 \pm 0.1$

Further addition of extra dosage has observed no significant increase in fluoride removal. The $40.0 \mathrm{~g}$ aloe vera and $3.0 \mathrm{~g} \mathrm{CaCl}_{2}$ in $1000 \mathrm{~mL}$ sample at $\mathrm{pH} 7.4 \pm 0.1$ was selected for optimisation of the method.

\section{Effect of contact time on fluoride removal}

The effect of contact time was studied by varying it from 10 to 60 minutes keeping $40.0 \mathrm{~g}$ aloe vera and $3.0 \mathrm{~g} \mathrm{CaCl}_{2}$ in $1000 \mathrm{~mL}$ sample at $\mathrm{pH}$ of $7.4 \pm 0.1$ as shown in Figure 4. It was observed that the removal of fluoride ions related to contact time with some extent. The removal efficiency became almost constant after 40 minute as indicated in Figure 4. For optimization of parameters, that contact time at $88 \%$ removal efficiency was considered as the equilibrium time.

\section{Effect of initial fluoride concentration on adsorption}

The effect of initial fluoride concentration was studied by varying it from 1.4 to $16.8 \mathrm{mg} \mathrm{L}^{-1}$ keeping $40.0 \mathrm{~g}$ aloe vera, $3.0 \mathrm{~g} \mathrm{CaCl}_{2}$ dose in $1000 \mathrm{ml}$ sample and contact time of 40 minute at 
$\mathrm{pH} 7.4 \pm 0.1$ as shown in Figure 5. It was observed that the percentage of fluoride removal decreased with increasing initial fluoride ion concentration as indicated in Figure 5. The maximum and minimum percentage of fluoride removal was observed to be $94 \%$ and $35 \%$ at an initial fluoride concentration of 1.4 and $16.8 \mathrm{mg} \mathrm{L}^{-1}$ respectively.

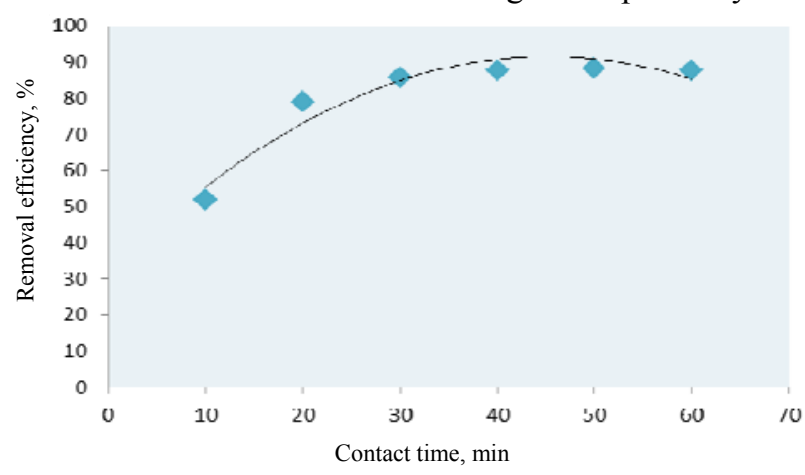

Figure 4. Effect of contact time on precipitation and adsorption of fluoride at $\mathrm{pH} 7.4 \pm 0.1$

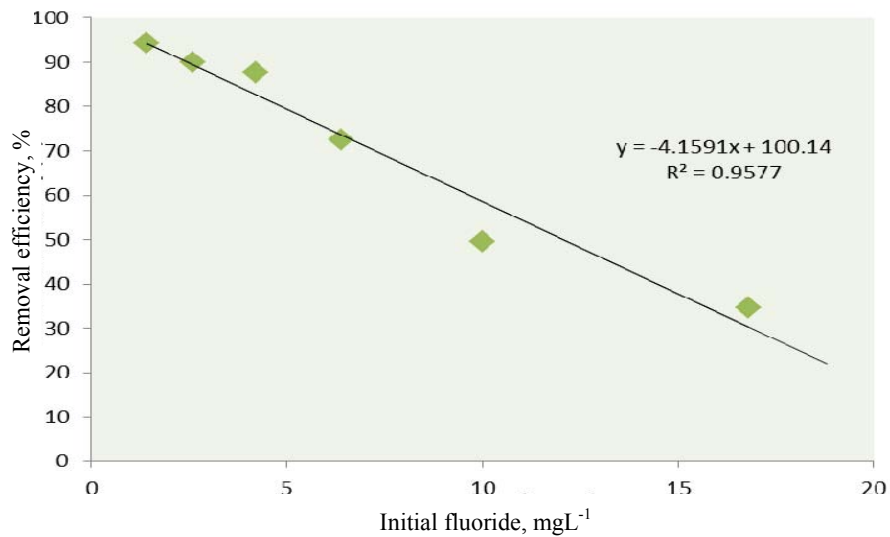

Figure 5. Effect of fluoride conc. On precipitation and adsorption of fluoride

\section{Adsorption isotherms}

The adsorption isotherms are essential to determine the feasibility of biomass for fluoride removal process. Moreover, these isotherms are important in the predictive modeling procedures for analysis and design for sorption systems ${ }^{23}$. In order to establish the maximum sorption capacity, the Langmuir and Freundlich isotherms have been used most frequently ${ }^{27-28}$.

\section{Freundlich isotherms}

The Freundlich adsorption values are calculated by the following reaction.

Freundlich equation

$$
\mathrm{x} / \mathrm{m}=\mathrm{K} \mathrm{C}^{1 / \mathrm{n}}
$$

Freundlich linear form

$$
\log (\mathrm{x} / \mathrm{m})=\log \mathrm{K}+1 / \mathrm{n} \log \mathrm{C}
$$

Where $\mathrm{x} / \mathrm{m}(\mathrm{mg} / \mathrm{g})$ is the amount of fluoride adsorbed $\left(\mathrm{mg} \mathrm{L}^{-1}\right)$ per unit weight $(\mathrm{g})$ of the aloe vera and $\mathrm{CaCl}_{2}$ in $1000 \mathrm{ml}$ sample, $\mathrm{C}$ is the equilibrium concentration of fluoride, $\mathrm{K}$ is the minimum sorption capacity $(\mathrm{mg} / \mathrm{g})$ and $1 / \mathrm{n}$ is the adsorption intensity. Linear plot of $\log$ C versus $\log (\mathrm{x} / \mathrm{m})$ at different fluoride ion concentration was obtained as shown in Figure 6. 


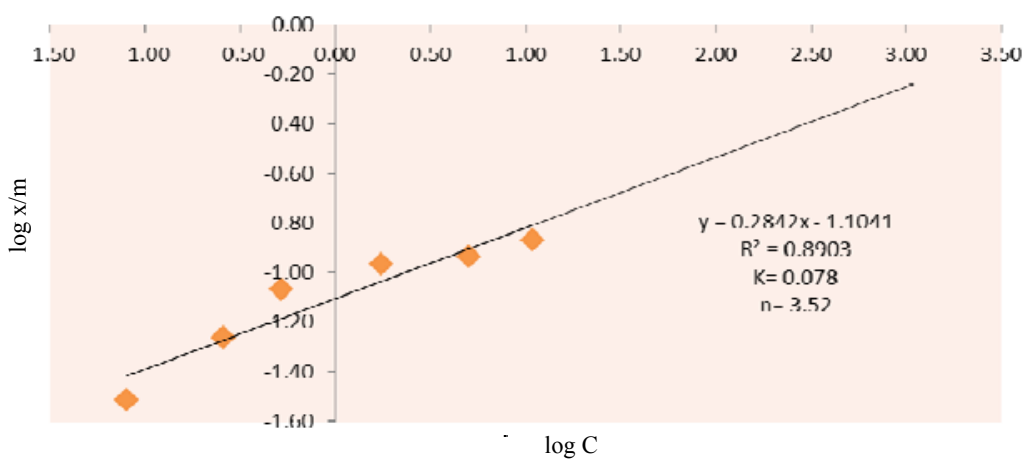

Figure 6. Freundlich isotherms for fluoride adsorption study

The Freundlich constant K and 1/n were calculated from intercept and slope of the graph as shown in Figure 6. The numerical value of minimum sorption capacity $(\mathrm{K})$ and adsorption intensity (n) for mass (aloe vera and $\mathrm{CaCl}_{2}$ ) were obtained at $0.078 \mathrm{mg} / \mathrm{g}$ and 3.52 respectively.

\section{Langmuir isotherms}

The Langmuir adsorption isotherm assumes the formations of monolayer coverage of adsorbate on outer surface of the adsorbent. This assumption is based on the point of valence exists on the surface of the adsorbent and that each of these sites is capable of adsorbing one molecule. Moreover, it is assumed that all the adsorption sites have equal affinity for molecules. The presence of adsorbed molecules at one site does not affect the adsorption on nearby sites. The Langmuir isotherm is given below:

$$
\begin{array}{cl}
\text { Langmuir equation } & \mathrm{x} / \mathrm{m}=\mathrm{abC} /(1+\mathrm{aC}) \\
\text { Langmuir linear form } & 1 /(\mathrm{x} / \mathrm{m})=1 / \mathrm{ab} \times 1 / \mathrm{C}+1 / \mathrm{b}
\end{array}
$$

Where $\mathrm{x} / \mathrm{m}(\mathrm{mg} / \mathrm{g})$ is the amount of fluoride adsorbed per unit weight of the biomass, $\mathrm{C}$ is the equilibrium concentration of fluoride. The Langmuir equilibrium constant a \& b are the energy sorption $\&$ amount of fluoride required to form a monolayer respectively.

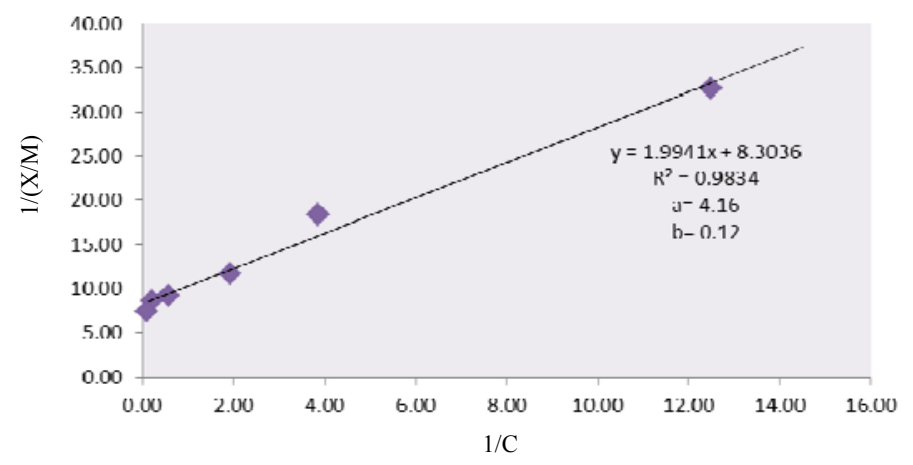

Figure 7. Langmuir isotherms for fluoride adsorption study

Linear plot of $1 / \mathrm{C}$ versus $1 /(\mathrm{x} / \mathrm{m})$ at different fluoride ion concentration was obtained as shown in Figure 7. The value for $1 / \mathrm{ab}$ and $1 / \mathrm{b}$ were calculated from slope and intercept of the graph. The numerical value of the energy of sorption (a) and amount of fluoride required (b) to form a monolayer were obtained at 4.16 and $0.12 \mathrm{mg} / \mathrm{g}$ respectively. 


\section{Conclusion}

The force responsible for precipitation and adsorption of fluoride with aloe vera and calcium chloride is supposed to be some columbic forces between the positively charged surface and negatively charged fluoride ions. Most probably, the calcium ions in aloe vera and calcium chloride react with negatively charged fluoride ions from the solution. The probable responsible ion in this process may be the hydrogen ion. It accelerates the positive charge on calcium which favors the precipitation and adsorption of fluoride. In favourable conditions, the fluoride may precipitate out as given below.

$$
\mathrm{Ca}^{2+}+2 \mathrm{~F}^{-} \rightarrow \mathrm{CaF}_{2}(\downarrow)
$$

The main mechanism may be through fluoride precipitation and adsorption $\left(\mathrm{CaF}_{2}\right)$ by aloe vera and calcium chloride as well as filtered through local available Sikar clay. The optimum fluoride removal (88\%) was achieved at $\mathrm{pH} 7.4 \pm 0.1$ with $40.0 \mathrm{~g}$ aloe vera, $3.0 \mathrm{~g}$ calcium chloride in $1000 \mathrm{~mL}$ sample and in a contact period of 40 minutes. Equilibrium adsorption data has followed both Langmuir and Freundlich isotherms.

\section{Acknowledgement}

We are thankful to the Institute for providing necessary facilities to complete this study. One of the authors, Radhey Shyam is also thankful to ONGC, Mumbai Region for giving the permission to carry out the research and posting him in 14 days on/off pattern at offshore.

\section{References}

1. CGWB, Annual report and other related reports on groundwater quality. New Delhi, Central Groundwater Board, 2004.

2. Fordyce F M, Vrana K, Zhovinsky E, Povoroznuk V, Toth G, Hope B C, Iljinsky U and Baker J, Environ Geochem Health, 2007, 29(2), 83-102; DOI:10.1007/s10653006-9076-7.

3. Rafique T, Naseem S, Bhanger M I and Usmani T H, Environ Geology, 2008, 56(2), 317-326; DOI:10.1007/s00254-007-1167-y.

4. Rao N S, Environ Monit Assess, 2009, 152, 47-60.

5. WHO, Fluoride in drinking water, London, IWA publishing, World Health Organization, 2006.

6. WHO, Guidelines for drinking water quality, Recommendations, Geneva, World Health Organization, 1996.

7. UNICEF, States of the art report on the extent of fluoride in drinking water and the resulting endemicity in India, New Delhi, Report by fluorosis and rural development foundation for UNICEF, 1999.

8. Hussain J, Hussain I and Sharma K C, Environ Monit Assess., 2010, 162(1-4), 1-14; DOI:10.1007/s10661-009-0771-6.

9. Shyam R and Kalwania G S, Environ Earth Sci., 2012, 65(4), 1275-1282; DOI:10.1007/s12665-011-1375-3.

10. SWRPD, State Water Policy 2010, Jaipur, State Water Resource Planning Department, Government of Rajasthan, 2010.

11. Suthar S, Garg V K, Jangir S, Kaur S, Nidhi Goswami and Sushma Singh, Environ Monit Assess., 2008, 145(1-3), 1-6; DOI:10.1007/s10661-007-0011-x.

12. Choubisa S L and Sompura K, Pollu Res., 1996, 15(1), 45-47.

13. Chaudhary V, Kumar M, Sharma M and Yadav B S, Environ Monit Assess., 2010, 161(1-4), 343-348; DOI:10.1007/s10661-009-0750-y. 
14. Saxena V and Ahmed S, Environ Geology, 2001, 40(9), 1084-1087; DOI: $10.1007 / \mathrm{s} 002540100290$.

15. Rao N S and Devadas D J, Environ Geology, 2003, 45(2), 243-251;

DOI:10.1007/s00254-003-0873-3.

16. Guo Q, Wang Y and Guo Q L, Environ Earth Sci, 2010, 60(3), 633-642;

DOI:10.1007/s12665-009-0203-5

17. Bulusu K R and Pathak B N, J Environ Eng., 1980, 106(2), 466- 469.

18. Fantong W Y, Satake H, Ayonghe S N, Suh E C, Segun M A Adelana, Emilia Bi S Fantong, Hycinth S Banseka, Cletus D Gwanfogbe, Leonard N Woincham, Yoshitoshi Uehara and Jing Zhang, Environ Geochem Health, 2010, 32(2), 147-163; DOI:10.1007/s10653-009-9271-4.

19. Meenakshi and Maheshwari R C, J Hazard Matter., 2006, 137(1), 456-463; DOI:10.1016/j.jhazmat.2006.02.024.

20. Jamodel A V, Sapkal V S and Jamode V S, J Indian Inst Sci., 2004, 84, 163-171.

21. Pandey P K, Pandey M and Sharma R, J Environ Protect., 2012, 3(7), 610-616; DOI:10.4236/jep.2012.37074.

22. Murugan M and Subramanian E, $J$ Water Health, 2006, 4(4), 453-461.

23. Jenish S and Methodis P A, Asian J Chem., 2011, 23(7), 2889-2892.

24. Bhatnagar M, Bhatnagar A and Jha S, Biotechnol Lett., 2002, 24(13), 1079-1081; DOI:10.1023/A:1016086631017.

25. Sinha S, Saxena R and Singh S, Bull Environ Contam Toxicol., 2000, 65(5), 683-690; DOI:10.1007/s0012800177.

26. Nawlakhe W G and Paramasivam R, Current Science, 1993, 65(10), 743-748.

27. Sivasankari C, Mahadevan M and Arulanantham A, Asian J Chem., 2010, 22(6), 4663-4670.

28. Lonare R, Inam F and Deo S, Asian J Chem., 2011, 23(1), 59-62.

29. Malakootian M, Moosazadeh M, Yousefi N and Fatehizadeh A, African J Environ Sci Technol., 2011, 5(4), 299-306; DOI:10.5897/AJEST10.308.

30. Togarepi E, Mahamadi C and Mangombe A, African J Environ Sci Technol., 2012, 6(3), 176-181; DOI:10.5897/AJEST11.270.

31. Chena N, Zhangb Z, Fenga C, Li M, Zhub D, Chenb R and Sugiurab N, J Hazard Mater., 2010, 183(1-3), 460-465; DOI:10.1016/j.jhazmat.2010.07.046.

32. Namasivayam C and Hoell W H, Int J Environ Pollu., 2008, 34(4), 203-214; DOI:10.1504/IJEP.2008.020792.

33. Rajasekaran S, Sivagnanam K and Subramanian S, Biolog Trace Element Res., 2005, 108(1-3), 185-195; DOI:10.1385/BTER:108:1-3:185.

34. Ranade A N, Wankhede S S, Ranpise N S and Mundada M S, AAPS Pharm Sci Tech., 2012, 13(4), 1518-1523; DOI:10.1208/s12249-012-9882-4.

35. Hamman J H, Molecules, 2008, 13(8), 1599-1616; DOI:10.3390/molecules13081599.

36. Rizzo A, Shibayama N and Kirby D P, Anal Bioanalytical Chem., 2011, 399(9), 3093-3107.

37. Arjunan N K, Murugan K, Madhiyazhagan P, Kovendan K, Prasannakumar K, Sundaram Thangamani and Donald R Barnard, Parasitol Res., 2011, 110(4), 14351443; DOI:10.1007/s00436-011-2646-3.

38. Genet W B M and van Schooten C A M, Irrigation Sci., 1992, 13(2), 81-85; DOI:10.1007/BF00193984.

39. APHA, Standard methods for the examination of water and waste water. $17^{\text {th }}$ Edn., Washington, D.C American Public Health Association, American Water Works Association, Water Pollution Control Federation, 1989. 